\title{
ANALISIS KEPATUHAN WAJIB PAJAK HOTEL BERDASARKAN PEMERIKSAAN PAJAK, SANKSI PERPAJAKAN, KONDISI KEUANGAN DAN PREFERENSI RESIKO PADA HOTEL-HOTEL YANG TERDAFTAR DI BAPPENDA KABUPATEN BOGOR
}

\section{ANALYSIS COMPLIANCE OF TAXPAYER HOTEL PURSUANT TO INSPECTION OF IEASE, SANCTION TAXATION, CONDITION OF FINANCE AND OF PREFERENSI RISK AT HOTELS WHICH ENLIST IN BAPPENDA SUB-PROVINCE OF BOGOR}

\author{
A.B. Setiawan, S. Meliana \\ Program Studi Akuntansi Fakultas Ekonomi Universitas Djuanda Bogor \\ Jl. Tol Ciawi No. 1, Kotak Pos 35, Kode Pos 16720, Telp/Fax : (0251) 8245155 \\ Email : ade.budi.setiawan@unida.ac.id,mely.meily26@gmail.com
}

\begin{abstract}
This research was aims to determine the influence of tax audit, tax penalties, financial condition and risk preference on tax compliance in paying taxes hotels at BAPPEDA (Revenue Service), Bogor. The population in this study are all registered taxpayer hotels in BAPPEDA (Revenue Service), Bogor .The sampling method used in this research is purposive sampling with criteria are accounting staff and tax professional of tax compliance in taxpayers hotels, who can't reach tax revenue targets during 20142015. The datas in this study was obtained by distributing questionnaires to 52 respondents on tax compliance in taxpayer hotels in Bogor City. This study was tested by using multiple linear regression analysis with SPSS 20.00 for windows. Based on the analysis result, it can be concluded that tax audit, tax penalties and financial condition had positive influence on tax compliance in taxpayer hotels at BAPPENDA (Revenue Service), Bogor. While risk preference, hasn't influence on tax compliance in taxpayer hotels at BAPPENDA (Revenue Service), Bogor.
\end{abstract}

Keyword : Tax Audit, Tax Penalties, Financial Condition, Risk Preference, Tax Compliance, Hotels Taxpayer

\begin{abstract}
ABSTRAK
Tujuan penelitian ini adalah untuk menguji pengaruh pemeriksaan pajak, sanksi perpajakan, kondisi keuangan dan preferensi risiko terhadap kepatuhan wajib pajak hotel. Populasi dalam penelitian ini adalah wajib pajak hotel yang terdaftar pada BAPPENDA Kabupaten Bogor. Metode penentuan sampel menggunakan teknik purposive sampling dengan kriteria staf keuangan dan perpajakan dari wajib pajak hotel yang tidak dapat memenuhi target penerimaan pajak hotel selama tahun 2014-2015. Data dalam penelitian ini diperoleh dengan cara menyebarkan kuesioner kepada 52 wajib pajak hotel. Penelitian ini diuji dengan menggunakan analisis regresi linear berganda dengan program SPSS 20.00 for windows. Berdasarkan hasil analisis dapat disimpulkan bahwa variabel pemeriksaan pajak, sanksi perpajakan dan kondisi keuangan berpengaruh positif dan signifikan terhadap kepatuhan wajib pajak hotel. Sedangkan preferensi resiko tidak berpengaruh terhadap kepatuhan wajib pajak hotel.
\end{abstract}

Kata kunci: Pemeriksaan Pajak, Sanksi Perpajakan, Kondisi Keuangan, Preferensi Resiko, Kepatuhan Wajib Pajak Hotel 


\section{PENDAHULUAN}

Pendapatan Asli Daerah (PAD) adalah pendapatan yang bersumber dan dipungut sendiri oleh pemerintah daerah. Sumber PAD terdiri dari: pajak daerah, retribusi daerah, laba dari badan usaha milik daerah (BUMD), dan Pendapatan Asli Daerah lainnya yang sah (Warsito, 2001:128). Menurut PP Nomor 91 Tahun 2010 Pasal 1 ayat 1 Pajak Daerah, yang selanjutnya disebut Pajak adalah kontribusi wajib kepada Daerah yang terutang oleh orang pribadi atau badan yang bersifat memaksa berdasarkan Undang-Undang, dengan tidak

Tabel 1. Kontribusi Pajak Daerah terhadap Pendapatan Asli Daerah pada Badan Pengelolaan Pendapatan Daerah Kabupaten Bogor

\begin{tabular}{ccccc}
\hline \multicolumn{2}{c}{ Keterangan } & PAD & Pajak Daerah & $\%$ \\
\hline \multirow{2}{*}{2014} & Target & $1.481 .027 .789 .100,00$ & $979.488 .814 .000,00$ & 66,14 \\
& Realisasi & $1.713 .376 .107 .983,00$ & $1.131 .443 .649 .696,16$ & 66,04 \\
\multirow{2}{*}{2015} & Target & $1.785 .300 .132 .000,00$ & $1.156 .238 .968 .000,00$ & 64,76 \\
& Realisasi & $1.988 .989 .280 .455,59$ & $1.289 .686 .458 .802,13$ & 64,84 \\
\hline
\end{tabular}

Sumber:Dispenda.bogorkab.go.id/Data diolah (2017)

Pajak sebagai penyumbang kontribusi terbesar terhadap PAD Kab. Bogor didukung oleh beberapa jenis pajak diantaranya adalah Pajak Hotel yang diatur dalam UU Nomor 28 Tahun 2009 dan PP Nomor 91 Tahun 2010 dan dituangkan dalam Perda Kabupaten Bogor Nomor 4 Tahun 2010 tentang Pajak Hotel dalam Pasal 1. Pajak Hotel adalah Pajak yang dikenakan atas pelayanan yang disediakan hotel.

Berdasarkan data yang diperoleh dari laporan penerimaan pendapatan daerah, data pendapatan pajak hotel secara keseluruhan realisasi Pajak Hotel tercapai melebihi target dengan masing-masing pencapaian tahun 2014 sebesar Rp. 44.871.730.571,61 atau sebesar 104,07\%, dan tahun 2015 sebesar Rp. 46.272.337.687,51 atau sebesar 100,74\%. Secara nominal pencapaian selama dua tahun ini mengalami peningkatan sebesar $\mathrm{Rp}$. 1.400.607.115,90 namun bila dilihat dari jumlah persentase mengalami penurunan sebesar 3,33\%.

Data pendapatan Pajak Hotel diperoleh dari hasil pelaporan wajib pajak Hotel

Tabel 2. Pendapatan Denda Pajak Hotel pada Badan Pengelolaan Pendapatan Daerah

Kabupaten Bogor Tahun 2014 dan 2015

\begin{tabular}{cccc}
\hline Pendapatan Denda Pajak Hotel & Target & Realisasi & $\%$ \\
\hline 2014 & $164.035 .000,00$ & $176.959 .220,28$ & $107,88 \%$ \\
2015 & $164.035 .000,00$ & $543.076 .976,08$ & $316,45 \%$ \\
\hline
\end{tabular}

Sumber:Dispenda.bogorkab.go.id/Data diolah (2017) menggunakan Self-Assesment System diatur dalam Perda Kabupaten Bogor Nomor 4 Tahun 2010. Trisnawati (2015:7), dalam sistem ini, wajib pajak diberi kepercayaan untuk menghitung sendiri jumlah pajak yang terhutang, yang dilaporkan melalui Surat Pemberitahuan Pajak Daerah (SPTPD). Dalam penerapan self assesment, beberapa fenomena yang terjadi dan menyebabkan pelaksanaan self assesment system dalam pemungutan pajak daerah tidak efektif.

Fenomena tersebut, tentu akan berpengaruh terhadap kepatuhan wajib pajak hotel. Kepatuhan wajib pajak hotel dapat diukur melalui beberapa indikator, diataranya: menyampaikan SPTPD sesuai dengan hitungan yang sebenarnya, menyampaikan secara tepat waktu, pembayaran secara tepat waktu dan sebagainya. Apabila wajib pajak tidak menyampaikan SPTPD dan pembayaran tepat waktu maka akan dikenakan sanksi administrasi berupa denda. Berikut ini merupakan data pendapatan dari denda pajak hotel yang disajikan dalam tabel berikut ini. mendapatkan imbalan secara langsung dan digunakan untuk keperluan daerah bagi tercermin dalam Laporan Penerimaan Pendapatan Daerah Kabupaten Bogor yang dikutip dari website (http://dispenda.bogorkab.go.id/index.php/m ultisite/page/1647), memberikan kontribusi yang cukup besar terhadap Pendapatan Asli Daerah (PAD). Kontribusi pajak daerah terhadap Pendapatan Asli Daerah rata-rata dianggarkan sekitar $65 \%$ pertahun. 
Data pendapatan denda pajak hotel pada tahun 2014 dan 2015 menggambarkan cukup tingginya ketidakpatuhan wajib pajak dalam membayar pajak tepat pada waktunya.Hal tersebut terlihat dari tingkat pendapatan denda pajak yang meningkat tajam.Namun demikian, kepatuhan wajib pajak hotel dapat pula dipengaruhi oleh beberapa hal yakni, pemeriksaan pajak, sanksi perpajakan, kondisi keuangan perusahaan dan preferensi resiko.

Pemeriksaan Pajak disinyalir dapat mempengaruhi kepatuhan wajib pajak Hotel. Pemeriksaan merupakan salah satu cara agar wajib pajak tetap berada dikoridor peraturan pajak dan fiskus dalam melaksanakan tugasnya agar wajib pajak tetap patuh dalam menjalankan hak dan kewajibannya membayar pajak (Hidayat, 2005). Pemeriksaan dilakukan untuk membuat wajib pajak yang ditemukan melakukan penyimpangan dalam pemenuhan kewajiban perpajakan agar menjadi lebih patuh dalam melakukan kewajiban perpajakannya (Dewi, 2016). Priantara, (2000:24), pemeriksaan pajak diharapkan akan menambah tingkat kepatuhan bagi wajib pajak karena salah satu tujuan penting dalam pemeriksaan adalah untuk menguji kepatuhan wajib pajak yang akan berdampak pada peningkatan penerimaan.

Selain pemeriksaan pajak, sanksi perpajakan juga dapat mempengaruhi Kepatuhan wajib pajak Hotel. Wajib pajak akan memenuhi kewajiban perpajakannya bila memandang bahwa sanksi perpajakan akan lebih banyak merugikannya. Sanksi diperlukan untuk memberikan pelajaran bagi pelanggar pajak (Jatmiko, 2006). Sanksi perpajakan dan audit adalah suatu kebijakan yang efektif untuk mencegah ketidakpatuhan wajib pajak (Ali, et.al. : 2001).

Kondisi keuangan dapat mempengaruhi wajib pajak. Kondisi keuangan dapat memperkuat atau bahkan memperlemah pengaruh pemeriksaan dan sanksi perpajakan terhadap kepatuhan wajib pajak. Bloomqist (2003), mengidentifikasi bahwa tekanan keuangan sebagai salah satu sumber tekanan bagi wajib pajak dan Bloomqist juga berpendapat bahwa wajib pajak yang mempunyai pendapatan yang terbatas mungkin akan menghindari pembayaran pajak jika kondisi keuangan wajib pajak tersebut buruk.
Peningkatan kepatuhan wajib pajak juga dapat dipengaruhi oleh preferensi wajib pajak akan risiko-risiko yang terjadi. Preferensi risiko merupakan salah satu karakteristik seseorang dimana karakteristik tesebut akan mempengaruhi perilakunya. Torgler (2003), menyampaikan bahwa keputusan seorang wajib pajak dapat dipengaruhi oleh perilakunya terhadap risiko yang dihadapi. Dalam menghadapi risiko-risiko tersebut setiap wajib pajak harus memiliki suatu keputusan untuk menghadapi atau menghindari risiko tersebut. Yulianty (2015), Risiko-risiko tersebut akan terkait dalam peningkatan kepatuhan wajib pajak, dimana seorang wajib pajak memiliki kecenderungan menentukan sikap dalam menghadapi risiko yang terjadi.

Berdasarkan Peraturan Daerah Kabupaten Bogor Nomor 4 Tahun 2010 tentang Pajak Hotel Pasal 1, Hotel adalah fasilitas penyedia jasa penginapan/peristirahatan termasuk jasa terkait lainnya dengan dipungut bayaran, yang mencakup juga motel, losmen, gubug pariwisata, wisma pariwisata, pesanggrahan, rumah penginapan dan sejenisnya, serta rumah kos dengan jumlah kamar lebih dari 10 (sepuluh). Pajak Hotel adalah Pajak yang dikenakan atas pelayanan yang disediakan hotel. Berdasarkan Peraturan Daerah Kabupaten Bogor Nomor 4 Tahun 2010 tentang Pajak Hotel Bab III yaitu, Pasal 5 mengenai Dasar pengenaan pajak adalah jumlah pembayaranatau yang seharusnya dibayar kepada Hotel.Pasal 6 ayat (1) Tarif pajak ditetapkan sebesar $10 \%$ (sepuluh per seratus).

Trisnawati (2015:36), Pemeriksaan pajak merupakan serangkaian kegiatan menghimpun dan mengolah data, keterangan dan atau bukti yang dilaksanakan secara obyektif dan proporsional suatu standar pemeriksaan untuk menguji kepatuhan pemenuhan kewajiban perpajakan dan atau untuk tujuan lain dalam rangka melaksanakan ketentuan undang-undang perpajakan.

Mardiasmo (2011:59), sanksi perpajakan merupakan bahwa ketentuan peraturan perundang-perundang perpajakan (norma perpajakan) akan dituruti atau ditaati atau dipatuhi. Atau bisa dengan kata lain sanksi perpajakan merupakan alat pencegah (preventif) agar wajib pajak tidak melanggar 
norma perpajakan. Rahayu (2015), ancaman terhadap pelanggaran suatu norma perpajakan ada yang diancam dengan sanksi administrasi saja, ada yang diancam dengan sanksi pidana saja dan ada pula yang diancam dengan sanksi administrasi dan sanksi pidana.

Rahayu (2015), sanksi administrasi dan sanksi pidana memiliki perbedaan yaitu sanksi administrasi merupakan pembayaran kerugian kepada negara, khususnya yang berupa bunga, denda dan kenaikan, sedangkan sanksi pidana berupa pidana kurungan atau pidana denda dan pidana yang berupa penjara. Kondisi keuangan perusahaan adalah persepsi tax professional tentang kemampuan perusahaan di mana tax professional bekerja. Laksono (2012:11), kondisi keuangan dapat didefinisikan dengan kemampuan keuangan perusahaan yang tercermin dari tingkat profitabilitas (profitability) dan arus kas (cash flow).

Aryobimo (2012:22), preferensi risiko merupakan salah satu karakteristik seseorang dimana akan mempengaruhi perilakunya (Sitkin \& Pablo, 1992). Dalam konseptual preferensi risiko terdapat tiga cakupan yaitu menghindari risiko, netral dalam menghadapi risiko, dan suka mencari risiko. Sebuah penelitian mengungkapkan bahwa perilaku wajib pajak dalam menghadapi risiko tidak dapat dianggap remeh dalam kaitannya dengan kepatuhan (Alm \& Torgler, 2006; Torgler, 2003). Torgler (2003) menyampaikan bahwa keputusan seorang wajib pajak dapat dipengaruhi oleh perilakunya terhadap risiko yang dihadapi.

Chaizi Nasucha (2004) dalam Sofyan (2005:45), Kepatuhan wajib pajak dapat diidentifikasi dari kepatuhan wajib pajak dalam mendaftarkan diri, kepatuhan untuk menyetorkan kembali Surat Pembeitahuan Pajak (SPT), kepatuhan dalam perhitungan dan pembayaran pajak terhutang, kepatuhan dalam pembayaran tunggakan.

\section{Pengembangan Hipotesis}

Hubungan Pemeriksaan Pajak, Sanksi Perpajakan, Kondisi Keuangan dan Preferensi Risiko Terhadap Kepatuhan Wajib Pajak

Pemeriksaan pajak, sanksi perpajakan, kondisi keuangan dan preferensi risiko secara bersama-sama memiliki keterkaitan satu sama lain dan secara bersama-sama berpengaruh terhadap kepatuhan wajib pajak hotel yang terdaftar di BAPPENDA Kabupaten Bogor.

\section{$\mathrm{H}_{1}$ : Pemeriksaan pajak, sanksi perpajakan, kondisi keuangan dan preferensi risiko berpengaruh secara simultan terhadap kepatuhan wajib pajak hotel}

\section{Hubungan Pemeriksaan Pajak Terhadap Kepatuhan Wajib Pajak}

Menurut Peraturan Direktur Jenderal Pajak Nomor PER-23/PJ/2013 tentang Standar Pemeriksaan,Pemeriksaan pajak merupakan serangkaian kegiatan menghimpun dan mengolah data, keterangan dan atau bukti yang dilaksanakan secara obyektif dan proporsional suatu standar pemeriksaan untuk menguji kepatuhan pemenuhan kewajiban perpajakan dan atau untuk tujuan lain dalam rangka melaksanakan ketentuan undang-undang perpajakan. Jika wajib pajak ditemukan melakukan penyimpangan dalam penemuhan kewajiban perpajakan untuk selanjutnya pemeriksaan pajak dapat meningkatkan kepatuhan wajib pajak yang berdampak pada peningkatan pendapatan.

\section{$\mathrm{H}_{2}$ : Pemeriksaan pajak berpengaruh terhadap kepatuhan wajib pajak hotel}

\section{Hubungan Sanksi Perpajakan Terhadap Kepatuhan Wajib Pajak} Mardiasmo (2011:59), Sanksi perpajakan merupakan bahwa ketentuan peraturan perundang-perundang perpajakan (norma perpajakan) akan dituruti atau ditaati atau dipatuhi. Atau bisa dengan kata lain sanksi perpajakan merupakan alat pencegah (preventif) agar wajib pajak tidak melanggar norma perpajakan. Jika wajib pajak memandang bahwa sanksi perpajakan akan memberikan banyak kerugian, untuk selanjutnya sanksi perpajakan dapat memberikan pelajaran bagi pelanggar pajak dan meningkatkan kepatuhan wajib pajak.

\section{$\mathrm{H}_{3}$ : Sanksi perpajakan berpengaruh terhadap kepatuhan wajib pajak hotel}

\section{Hubungan Kondisi Keuangan Terhadap Kepatuhan Wajib Pajak}

Laksono (2012:11), Kondisi keuangan adalah kemampuan keuangan perusahaan yang tercermin dari tingkat profitabilitas 
(profitability) dan arus kas (cash flow). Perusahaan yang mempunyai profitabilitas tinggi cenderung melaporkan pajaknya dengan jujur dari pada perusahaan yang mempunyai profitabilitas rendah. Perusahaan dengan profitabilitas rendah pada umumnya mengalami kesulitan keuangan (financial difficulty) dan cenderung melakukan ketidakpatuhan pajak. Dengan tingkat beban hutang yang tinggi, ada kemungkinan mempengaruhi kepatuhan perusahaan dalam mematuhi peraturan perpajakan. Jika wajib pajak memiliki kondisi keuangan yang cukup baik dan cenderung stabil, untuk selanjutnya kondisi keuangan dapat meningkatkan kepatuhan wajib pajak.

\section{$\mathbf{H}_{4} \quad$ : Kondisi keuangan berpengaruh terhadap kepatuhan wajib pajak hotel}

\section{Hubungan Preferensi Resiko Terhadap Kepatuhan Wajib Pajak}

Aryobimo (2012:22), Dalam konseptual preferensi resiko terdapat tiga cakupan yaitu menghindari resiko, netral dalam menghadapi resiko, dan suka mencari risiko. Dalam teori prospek menerangkan bahwa ketika wajib pajak mempunyai tingkat resiko yang tinggi maka akan dapat mempengaruhi kepatuhan wajib pajak. Oleh karena itu, ketika kepatuhan pajak memiliki hubungan yang kuat dengan preferensi resiko maka tingkat kepatuhan wajib pajak akan rendah artinya wajib pajak memiliki berbagai resiko yang tinggi akan dapat menurunkan tingkat kepatuhan wajib pajak. Selanjutnya jika wajib pajak memiliki preferensi resiko yang rendah maka preferensi risiko dapat meningkatkan kepatuhan wajib pajak.

\section{$\mathrm{H}_{5} \quad$ : Preferensi resiko berpengaruh terhadap kepatuhan wajib pajak hotel}

\section{METODE PENELITIAN}

Objek dalam penelitian ini adalah Wajib Pajak Hotel yang terdaftar di BAPPENDA Kab. Bogor dengan staff accounting dan pajak yang bekerja di hotel tersebut yang telah bekerja selama 1 tahun sebagai responden. Penelitian ini dilaksanakan di masing-masing alamat Wajib Pajak Hotel yang terdaftar di BAPPENDA Kab. Bogor

\section{Operasional Variabel}

1. Pemeriksaan Pajak $\left(\mathrm{X}_{1}\right)$, peneliti menggunakan indikator berdasarkan Peraturan Direktur Jenderal Pajak Nomor PER-9/PJ/2010:
a. Integritas Pemeriksa
b. Memeriksa di Tempat WP
c. Memeriksaatas buku, catatan, dan dokumen.
d. Memberitahukan hasil Pemeriksaan kepada WP
e. Memberikan kesempatan kepada WP untuk menyampaikan pendapat dan sanggahan.
f. Melakukan sidang penutup (Closing Conference)

2. Sanksi Perpajakan $\left(\mathrm{X}_{2}\right)$, peneliti menggunakan indikator Adam Smith diantaranya:
a. Sanksi harus jelas.
b. Sanksi tidak mengenal kompromi dan toleransi.
c. Sanksi yang diberikan hendaklah seimbang.
d. Sanksi memberikan efek jera.

3. Kondisi Keuangan $\left(\mathrm{X}_{3}\right), \quad$ peneliti menggunakan indikator memodifikasi instrumen yang dikembangkan oleh Bradley (1994) dan Siahaan (2005) yang terdiri dari:
a. Kondisi arus kas (cash flow) tahun terakhir
b. Kondisi laba sebelum pajak (earning before tax) tahun terakhir
c. Beban hutang (debt burden)

4. Preferensi Resiko $\left(\mathrm{X}_{4}\right)$, peneliti menggunakan indikator menurut Nicholson et al (2005) dalam Adiasa (2013) diantaranya:
a. Resiko Keuangan
b. Resiko Sosial
c. Resiko Pekerjaan

5. Kepatuhan wajib pajak (Y), peneliti menggunakan indikator dengan memodifikasi intrumen yang dikembangkan oleh Chaizi Nasucha (2004) dan Alim (2005), diantaranya:
a. Memiliki NPWPD
b. Tepat waktu menyampaikan SPT atau SPTPD
c. Patuh dalam perhitungan dan pembayaran pajak terhutang
d. Tidak mempunyai tunggakan pajak
e. Tidak pernah dijatuhi hukuman pidana dibidang perpajakan


f. Menyelenggarakan pembukuan

\section{Populasi dan Sampel Penelitian}

Populasi dalam penelitian ini adalah wajib pajak hotel yang terdaftar di Badan Pengelolaan Pendapatan Daerah Kabupaten Bogor tahun 2015 yang dikelompokan berdasarkan klasifikasi hotel dengan jumlah keseluruhan sebanyak 307 wajib pajak. Dalam penelitian ini penulis menggunakan teknik sampling nonprobabilty yaitu purposive sampling menggunakan kriteria bahwa yang menjadi sampel dalam penelitian ini adalah hotel yang termasuk dalam klasifikasi yang tidak memenuhi target penerimaan pajak hotel selama tahun 2014 dan 2015 yang tercantum dalam Laporan Penerimaan Pendapatan Daerah Kabupaten Bogor yang terdiri dari Hotel Bintang 3 sebanyak 12, Hotel Bintang 4 sebanyak 3, Hotel Bintang 5 sebanyak 1 dan Melati 2 sebanyak 36 dengan jumlah keseluruhan 52 sampel.

\section{Metode Analisis Data}

Tabel 3. Hasil Uji Validitas Instrumen

\begin{tabular}{ccccc} 
& \multicolumn{3}{c}{ Tabel 3. Hasil Uji Validitas Instrumen } & \\
\hline \multirow{2}{*}{ Variabel } & $\begin{array}{c}\text { Item Pertanyaan } \\
\text { Ke- }\end{array}$ & $\begin{array}{c}\text { Nilai Pearson } \\
\text { Correlation }\end{array}$ & $\begin{array}{c}2 \text { Tailed } \\
(5 \%)\end{array}$ & Status \\
\hline P2 & 0,555 & 0,285 & Valid \\
& P3 & 0,634 & 0,285 & Valid \\
& P4 & 0,688 & 0,285 & Valid \\
& P5 & 0,755 & 0,285 & Valid \\
Sanksi Perpajakan Pajak & P6 & 0,670 & 0,285 & Valid \\
& S1 & 0,739 & 0,285 & Valid \\
& S2 & 0,481 & 0,285 & Valid \\
& S3 & 0,744 & 0,285 & Valid \\
& S4 & 0,657 & 0,285 & Valid \\
& K1 & 0,660 & 0,285 & Valid \\
& K2 & 0,824 & 0,285 & Valid \\
Preferensi Resiko & K3 & 0,905 & 0,285 & Valid \\
& PR1 & 0,848 & 0,285 & Valid \\
& PR2 & 0,483 & 0,285 & Valid \\
& PR3 & 0,686 & 0,285 & Valid \\
& PR4 & 0,754 & 0,285 & Valid \\
& PR5 & 0,837 & 0,285 & Valid \\
& KW1 & 0,629 & 0,285 & Valid \\
& KW2 & 0,766 & 0,285 & Valid \\
& KW3 & 0,684 & 0,285 & Valid \\
& KW4 & 0,765 & 0,285 & Valid \\
& KW5 & 0,559 & 0,285 & Valid \\
& KW6 & 0,575 & 0,285 & Valid \\
\hline & & & &
\end{tabular}

Metode analisis data yang digunakan dalam penelitian ini diantaranya Analisis Statistik Deskriptif, Analisis Regresi Linear Berganda, Analisis Korelasi dan Determinasi, Pengujian Hipotesis (Uji Simultan (F) dan Uji Parsial (t)) dengan bantuan Software SPSS 20.00 for Windows.

\section{HASIL DAN PEMBAHASAN}

Penelitian dilakukan dengan penyebaran kuesioner kepada responden secara langsung, yang dilakukan dengan memohon izin kepada HRD Hotel, kemudian setelah diberikan izin untuk bertemu langsung dengan bagian staff accounting dan pajak. Hasil pengumpulan angket atau kuesioner yang disebar adalah sebanyak 52 angket (100\%) sedangkan kuesioner yang kembali dan memenuhi syarat adalah sebanyak 48 (92\%).

\section{Uji Kualitas Data}


Berdasarkan tabel 3 di atas, hasil uji validitas diperoleh lima output yang terdiri dari pemeriksaan pajak $\left(\mathrm{X}_{1}\right)$, sanksi perpajakan $\left(\mathrm{X}_{2}\right)$, kondisi keuangan $\left(\mathrm{X}_{3}\right)$, preferensi resiko $\left(\mathrm{X}_{4}\right)$ dan kepatuhan wajib pajak (Y). Data tersebut menunjukkan bahwa semua memiliki nilai validitas diatas 0,285 , sehingga dapat dinyatakan semua item pernyataan valid.

\section{Uji Reliabilitas}

Tabel 4. Hasil Uji Reliabilitas Instrumen

\begin{tabular}{lcc}
\hline \multicolumn{1}{c}{ Variabel } & Nilai Cronbach's Alpha & Status (Menurut Ghozali) \\
\hline Pemeriksaan Pajak & 0,767 & Reliabel \\
Sanksi Perpajakan & 0,748 & Reliabel \\
Kondisi Keuangan & 0,848 & Reliabel \\
Preferensi Risiko & 0,786 & Reliabel \\
Kepatuhan Wajib Pajak & 0,752 & Reliabel \\
\hline
\end{tabular}

Sumber: Data Primer Diolah (2017)

Berdasarkan tabel 4. dapat disimpulkan bahwa keempat variabel instrumen yang digunakan reliabel atau memiliki kehandalan jika pengukuran diulang yakni variabel pemeriksaan pajak, sanksi perpajakan, kondisi keuangan, preferensi resiko dan kepatuhan wajib pajak. Hal ini dibuktikan dengan hasil pengujian yang menyatakan bahwa variabelvariabel memiliki nilai alpha lebih dari 0,6.

\section{Analisis Statistik Deskriptif}

Tabel 5. Statistik Deskriptif

\begin{tabular}{lccccc}
\hline & N & Min & Max & Mean & Std. Deviation \\
\hline Pemeriksaan Pajak & 48 & 19,00 & 30,00 & 25,00 & 2,325 \\
Sanksi Perpajakan & 48 & 8,00 & 19,00 & 14,69 & 2,002 \\
Kondisi Keuangan & 48 & 3,00 & 12,00 & 7,56 & 2,062 \\
Preferensi Resiko & 48 & 8,00 & 25,00 & 17,48 & 3,489 \\
Kepatuhan WP & 48 & 21,00 & 30,00 & 24,81 & 2,481 \\
Valid N (listwise) & 48 & & & & \\
\hline
\end{tabular}

Sumber: Data Primer Diolah (2017)

Hasil pengolahan data yang terlihat pada tabel 5 menunjukkan bahwa standar deviasi lebih kecil dibandingkan dengan nilai mean. Hal ini menunjukkan bahwa nilai sampel dominan berkumpul di sekitar rata-rata hitungnya.

\section{Uji Asumsii Klasik Uji Normalitas}

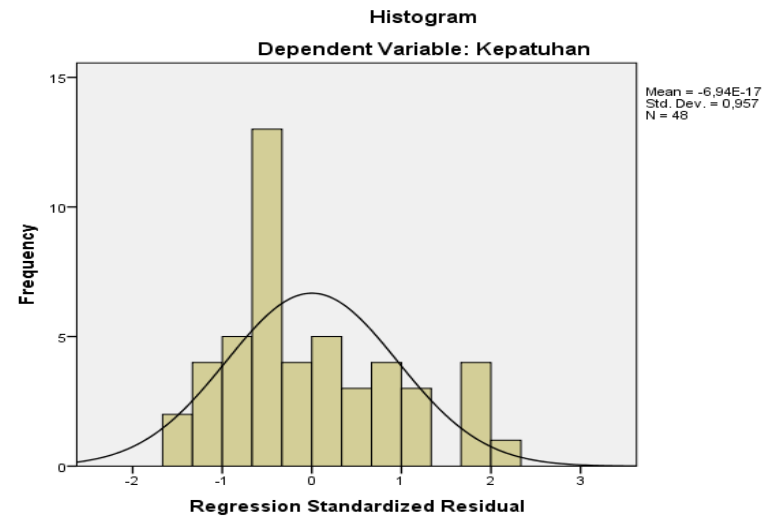

\section{Gambar 1 Grafik Histogram Sebaran Data Wajib Pajak Hotel}

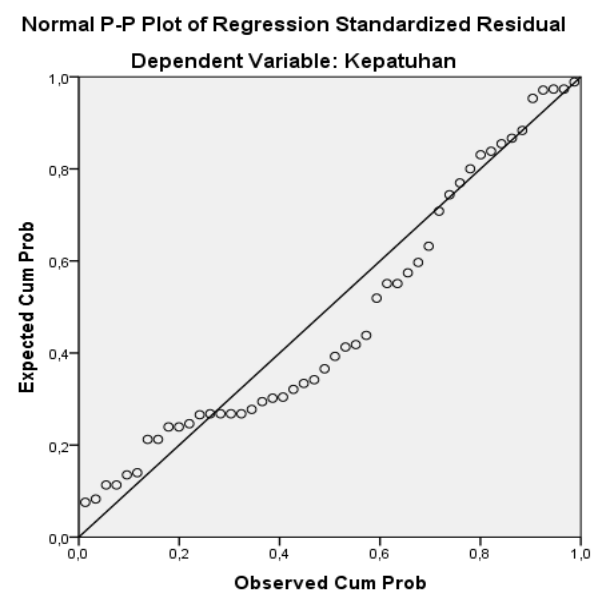

Gambar 2 Grafik P-P Plot Regression Sebaran Data Wajib Pajak Hotel 
Tabel 6. Hasil Uji Normalitas dengan One Sample Kolomogorov Smirnov

\begin{tabular}{llr}
\hline & & \multicolumn{2}{c}{ Unstandardized Residual } \\
\hline $\mathrm{N}$ & Mean & 48 \\
Normal Parametersa,b & Std. Deviation &, 0000000 \\
& Absolute & 2,07203491 \\
Most Extreme Differences & Positive &, 148 \\
& Negative &, 148 \\
Kolmogorov-Smirnov Z & &,- 077 \\
Asymp. Sig. (2-tailed) & & 1,024 \\
a. Test distribution is Normal. & &, 245 \\
b. Calculated from data. & & \\
\hline Sumber: Data Primer Diolah (2017) & &
\end{tabular}

Sumber: Data Primer Diolah (2017)

Berdasarkan Tabel 6 dapat diketahui bahwa nilai signifikansi atau asymp. Sig. Untuk uji dua arah adalah 0,245, dengan demikian nilai signifikansi lebih besar dari 0,05 (0,245 >
0,05). Dapat disimpulkan bahwa model regresi yang diuji berdistribusi normal.

Uji Multikolinearitas

Tabel 7. Hasil Uji Multikolinearitas dengan Metode VIF

\begin{tabular}{|c|c|c|c|}
\hline \multicolumn{4}{|c|}{ Coefficients ${ }^{a}$} \\
\hline & \multirow{2}{*}{ Model } & \multicolumn{2}{|c|}{ Collinearity Statistics } \\
\hline & & Tolerance & $V I F$ \\
\hline \multirow[t]{5}{*}{1} & (Constant) & & \\
\hline & Pemeriksaan Pajak & .666 & 1.502 \\
\hline & Sanksi Perpajakan & .840 & 1.191 \\
\hline & Kondisi Keuangan & .501 & 1.996 \\
\hline & Preferensi Risiko & .443 & 2.256 \\
\hline
\end{tabular}

a. Dependent Variable: Kepatuhan Wajib Pajak Hotel

Sumber: Data Primer Diolah (2017)

Berdasarkan Tabel 7 Keempat variabel independen tersebut memiliki nilai VIF yang lebih kecil dari $10(\mathrm{VIF}<10)$ dan memiliki nilai tolerance lebih dari 0,1 maka dapat dikatakan bahwa model regresi tidak terjadi gejala multikolinearitas atau non multikolinearitas.

Uji Heteroskedastisitas

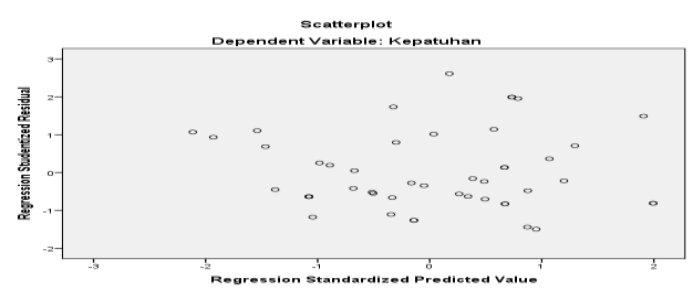

Gambar 3. Hasil Uji Keteroskedastisitas dengan Metode Scatter Plots Regression

Tabel 8. Hasil Uji Heteroskedastisitas dengan Uji Glejser

\begin{tabular}{|c|c|c|c|c|c|c|}
\hline & \multirow[t]{2}{*}{ Model } & \multicolumn{2}{|c|}{$\begin{array}{l}\text { Unstandardized } \\
\text { Coefficients }\end{array}$} & \multirow{2}{*}{$\begin{array}{c}\text { Standardized } \\
\text { Coefficients } \\
\text { Beta }\end{array}$} & \multirow[t]{2}{*}{$\mathrm{t}$} & \multirow[t]{2}{*}{ Sig. } \\
\hline & & B & Std. Error & & & \\
\hline \multirow[t]{5}{*}{1} & (Constant) & $-2,105$ & 3,655 & &,- 576 & ,568 \\
\hline & Pemeriksaan Pajak & ,149 & 089 & 301 & 1,668 & 103 \\
\hline & Sanksi Perpajakan &,- 041 & 092 &,- 071 &,- 439 & 663 \\
\hline & Kondisi Keuangan & ,032 & 116 & ,058 & ,278 & ,782 \\
\hline & Preferensi Risiko & 025 & ,073 & 075 & ,338 & ,737 \\
\hline
\end{tabular}

a. Dependent Variable: ABS_RES

Sumber: Data Primer Diolah (2017) 
Berdasarkan hasil uji glejser yang tertera pada Tabel 8 di atas, dapat diketahui bahwa nilai signifikansi keempat variabel independen bernilai lebih dari 0,05. Dengan demikian dapat disimpulkan bahwa tidak terjadi masalah heteroskedastisitas pada model regresi.

\section{Analisis Regresi Linear Berganda}

Tabel 9. Hasil Analisis Regresi Linier Berganda

\begin{tabular}{llrrrrr}
\hline \multirow{2}{*}{ Model } & \multicolumn{2}{c}{ Unstandardized Coefficients } & $\begin{array}{c}\text { Standardized } \\
\text { Coefficients }\end{array}$ & T & Sig. \\
\cline { 3 - 7 } & \multicolumn{1}{c}{ B } & \multicolumn{2}{c}{ Std. Error } & Beta & & \\
\hline 1 & (Constant) &, 479 & 6,807 & &, 070 &, 944 \\
& Pemeriksaan Pajak &, 386 &, 167 &, 361 & 2,316 &, 025 \\
& Sanksi Perpajakan &, 413 &, 172 &, 333 & 2,396 &, 021 \\
& Kondisi Keuangan &, 577 &, 217 &, 480 & 2,666 &, 011 \\
& Preferensi Risiko &, 244 &, 136 &, 343 & 1,792 &, 080 \\
\hline
\end{tabular}

Sumber: Data Primer Diolah (2017)

Berdasarkan data yang terdapat dalam tabel 9, maka dapat disusun persamaan regresi linier sebagai berikut.

$Y=0,479+0,386 X_{1}+0,413 X_{2}+0,577 X_{3}+$ $0,244 \mathrm{X}_{4}$

Interprestasi persamaan $\mathrm{di}$ atas dapat diuraikan sebagai berikut:

a. Konstanta sebesar 0,479 artinya jika pemeriksaan pajak, sanksi perpajakan, kondisi keuangan, preferensi risiko bernilai 0 maka kepatuhan wajib pajak bernilai 0,479 tingkat.

b. Koefisien regresi variabel pemeriksaan pajak $\left(\mathrm{X}_{1}\right)$ sebesar 0,386 bertanda positif, artinya jika variabel independen lainnya bernilai tetap dan variabel pemeriksaan pajak mengalami kenaikan 1 tingkat, maka kepatuhan wajib pajak (Y) akan mengalami kenaikan sebesar 0,386 tingkat.

c. Koefisien regresi variabel sanksi perpajakan $\left(\mathrm{X}_{2}\right)$ sebesar 0,413 bertanda positif, artinya jika variabel independen lainnya bernilai tetap dan variabel sanksi perpajakan mengalami kenaikan 1 tingkat, maka kepatuhan wajib pajak (Y) akan mengalami kenaikan sebesar 0,413 tingkat.

d. Koefisien regresi variabel kondisi keuangan $\left(\mathrm{X}_{3}\right)$ sebesar 0,577 bertanda positif artinya jika variabel independen lainnya bernilai tetap dan variabel kondisi keuangan mengalami kenaikan 1 tingkat, maka kepatuhan wajib pajak (Y) akan mengalami penurunan sebesar 0,577 tingkat.

e. Koefisien regresi variabel preferensi risiko $\left(\mathrm{X}_{4}\right)$ sebesar 0,244 bertanda positif, artinya jika variabel independen lainnya bernilai tetap dan variabel preferensi risiko mengalami kenaikan 1 tingkat, maka kepatuhan wajib pajak (Y) akan mengalami kenaikan sebesar 0,244 tingkat.

\section{Koefisien Korelasi}

Tabel 10. Hasil Analisa Korelasi Berganda

\begin{tabular}{ccccc}
\multicolumn{5}{c}{ Model Summary $^{\mathrm{b}}$} \\
\hline Model & $\mathrm{R}$ & $\mathrm{R}$ Square & Adjusted R Square & Std. Error of the Estimate \\
\hline 1 &, $550^{\mathrm{a}}$ &, 303 &, 238 & 2,166 \\
\hline
\end{tabular}

a. Predictors: (Constant), Preferensi Risiko, Sanksi Perpajakan, Pemeriksaan Pajak, Kondisi Keuangan

b. Dependent Variable: Kepatuhan Wajib Pajak

Sumber: Data Primer Diolah (2017)

Berdasarkan tabel $10 \mathrm{di}$ atas diperoleh angka $R$ sebesar 0,550 angka ini menunjukan tingkat hubungan yang cukup kuat antara variabel Pemeriksaan Pajak, Sanksi Perpajakan, Kondisi Keuangan, dan Preferensi Resiko dengan variabel Kepatuhan Wajib Pajak.

\section{Koefisien Determinasi}

Berdasarkan Tabel 4.8 angka $\mathrm{R}$ square atau koefisien determinasi adalah 0,303 (berasal dari 0,550 x 0,550). Hal ini berarti $30,3 \%$ variasi dari kepatuhan wajib pajak dapat dijelaskan oleh variasi dari keempat variabel independen, sedangkan sisanya 
$(100 \%-30,3 \%=69,7 \%)$ dijelaskan oleh sebab-sebab lain atau dijelaskan oleh variabel lain yang tidak dimasukkan dalam model penelitian ini. Nilai adjusted $R$ square (nilai $\mathrm{R}$ square yang telah disesuaikan) yaitu 0,238 selalu lebih kecil dari R Square yang artinya nilai $\mathrm{R}^{2}$ yang disesuaikan terhadap variabel bebas yang berarti $30,3 \%$ variabel bebas dapat menjelaskan variabel terikatnya sedangkan sisanya $69,7 \%$ dijelaskan oleh variabel lain diluar model yang tidak diteliti dalam penelitian ini. Standard Error of the Estimate adalah suatu ukuran banyaknya kesalahan model regresi dalam memprediksi nilai Y. Dari hasil regresi didapat nilai 2,166 atau 2,166 tingkat, hal ini berarti banyaknya kesalahan dalam prediksi kepatuhan wajib pajak sebesar 2,166 tingkat.

\section{Pengujian Hipotesis Uji F (Uji Simultan)}

Tabel 11. Hasil Uji F (Uji Simultan)

ANOVA $^{\mathrm{a}}$

\begin{tabular}{llccccc}
\hline & Model & Sum of Squares & $\mathrm{df}$ & Mean Square & $\mathrm{F}$ & Sig. \\
\hline 1 & Regression & 87,526 & 4 & 21,882 & 4,663 &, $003^{\mathrm{b}}$ \\
& Residual & 201,786 & 43 & 4,693 & & \\
& Total & 289,313 & 47 & & & \\
\hline
\end{tabular}

a. Dependent Variable: Kepatuhan Wajib Pajak

b. Predictors: (Constant), Pemeriksaan Pajak, Sanksi Perpajakan, Kondisi Keuangan, Preferensi Risiko

Sumber: Data Primer Diolah (2017)

Berdasarkan Tabel 11 nilai $\mathrm{F}_{\text {hitung }}$ lebih besar daripada $\mathrm{F}_{\text {tabel }}(4,663>2,589)$, maka $\mathrm{H}_{0}$ ditolak dan $\mathrm{H}_{\mathrm{a}}$ diterima, artinya terdapat pengaruh secara signifikan antara pemeriksaan pajak, sanksi perpajakan, kondisi keuangan dan preferensi resiko secara bersama-sama terhadap kepatuhan wajib pajak. Jadi, dari hasil penelitian ini dapat disimpulkan bahwa pemeriksaan pajak, sanksi perpajakan, kondisi keuangan dan preferensi risiko secara bersama-sama berpengaruh terhadap kepatuhan wajib pajak hotel yang terdaftar di BAPPENDA Kabupaten Bogor.

\section{Uji t (Uji Parsial)}

Tabel 12. Hasil Uji t (Uji Parsial)

\begin{tabular}{lcc}
\hline Model & T & Sig. \\
\hline & &, 944 \\
Pemeriksaan Pajak & 2,316 &, 025 \\
Sanksi Perpajakan & 2,396 &, 021 \\
Kondisi Keuangan & 2,666 &, 011 \\
Preferensi Risiko & 1,792 &, 080 \\
\hline
\end{tabular}

Sumber: Data Primer Diolah (2017)

Berdasarkan Tabel 12, dengan nilai tabel sebesar 2,0167, Maka dapat disimpulkan bahwa secara parsial, variabel preferensi resiko tidak berpengaruh terhadap kepatuhan wajib pajak terlihat dari nilai $t_{\text {hitung }}<t_{\text {tabel }}$ sedangkan variabel pemeriksaan pajak, sanksi perpajakan, kondisi keuangan berpengaruh signifikan terhadap kepatuhan wajib pajak terlihat dari nilai $t_{\text {hitung }}<t_{\text {tabel }}$ dengan nilai signifikan $<0,05$.

\section{PEMBAHASAN}

Uji F

Berdasarkan hasil pengolahan data menunjukan ketiga variabel secara simultan berpengaruh terhadap kepatuhan wajib pajak.
Hal ini ditunjukan dengan $F_{\text {hitung }}>F_{\text {tabel }}$ dan probabilitas < tarif signifikansi. Berdasarkan pengolahan data tersebut, dapat disimpulkan bahwa terdapat pengaruh yang signifikan antara pajak, sanksi perpajakan, kondisi keuangan dan preferensi resiko dengan kepatuhan wajib pajak, sehingga keempat variabel independen tersebut secara simultan dapat memicu peningkatan pada tingkat kepatuhan wajib pajak. Dengan demikian hipotesis pertama $\left(\mathrm{H}_{1}\right)$ dapat diterima. Hal tersebut menunjukkan bahwa semakin efektif kebijakan perpajakan (pemeriksaan pajak dan sanksi perpajakan) yang didukung dengan kondisi keuangan wajib pajak yang baik serta diimbangi dengan semakin tingginya 
preferensi yang dimiliki wajib pajak dalam menghadapi resiko maka membuat semakin tinggi tingkat kepatuhan dari wajib pajak.

\section{Uji t}

a. $\mathrm{H}_{2}=$ Pemeriksaan Pajak berpengaruh terhadap Kepatuhan Wajib Pajak.

Hipotesis kedua $\left(\mathrm{H}_{2}\right)$ yang diajukan dalam penelitian ini adalah bahwa pemeriksaan pajak berpengaruh terhadap kepatuhan wajib pajak. Dengan kata lain, dengan adanya pemeriksaan pajak dapat meningkatkan tingkat kepatuhan wajib pajak. Hasil pengolahan data menunjukan pemeriksaan pajak berpengaruh terhadap tingkat kepatuhan wajib pajak. Dengan demikian hipotesis kedua $\left(\mathrm{H}_{2}\right)$ diterima. Adanya pengaruh pemeriksaan pajak terhadap kepatuhan wajib pajak dalam penelitian ini, disimpulkan sama oleh Dewi dan Sukartha (2015) serta Trisnawati (2015). Ketiga peneliti tersebut membuktikan bahwa variabel pemeriksaan pajak berpengaruh positif dan signifikan terhadap kepatuhan wajib pajak. Hal ini sejalan dengan pernyataan yang di kutip dalam Priantara (2000:24), bahwa pemeriksaan pajak diharapkan dapat menambah tingkat kepatuhan bagi wajib pajak karena salah satu tujuan penting dalam pemeriksaan adalah untuk menguji kepatuhan wajib pajak yang akan berdampak pada peningkatan penerimaan.

b. $\mathrm{H}_{3}=$ Sanksi Perpajakan berpengaruh terhadap Kepatuhan Wajib Pajak.

Hipotesis ketiga $\left(\mathrm{H}_{3}\right)$ yang diajukan dalam penelitian ini adalah bahwa sanksi perpajakan berpengaruh terhadap kepatuhan wajib pajak. Dengan kata lain, dengan adanya kebijakan sanksi perpajakan dapat meningkatkan tingkat kepatuhan wajib pajak. Semakin efektif kebijakan ini maka semakin tinggi pula kepatuhan dari wajib pajak. Hasil pengolahan data menunjukan bahwa secara parsial sanksi perpajakan berpengaruh terhadap kepatuhan wajib pajak. Dengan demikian hipotesis ketiga $\left(\mathrm{H}_{3}\right)$ diterima. Adanya pengaruh sanksi perpajakan terhadap kepatuhan wajib pajak dalam penelitian ini, disimpulkan sama oleh Dewi dan Sukartha (2015) serta Pratiwi dan Supadmi (2016). Keempat peneliti tersebut membuktikan bahwa variabel sanksi perpajakan berpengaruh positif dan signifikan terhadap kepatuhan wajib pajak. Dengan adanya sanksi perpajakan, wajib pajak hotel akan lebih patuh terhadap kewajiban perpajakannya bila memandang bahwa sanksi perpajakan akan lebih banyak memberikan kerugian sehingga sanksi ini akan memberikan pelajaran bagi pelanggar (Jatmiko, 2006) disamping menjadi kebijakan efektif untuk mencegah (preventif) atas ketidakpatuhan wajib pajak (Ali, et al, 2000), sehingga dapat menekan tingginya denda administrasi yang terjadi di BAPPENDA Kabupaten Bogor yakni sebesar 107,88\% pada tahun 2014 dan 316,45\% pada tahun 2015.

c. $\mathrm{H}_{4}=$ Kondisi Keuangan berpengaruh terhadap Kepatuhan Wajib Pajak.

Hipotesis keempat $\left(\mathrm{H}_{4}\right)$ yang diajukan dalam penelitian ini adalah bahwa kondisi keuangan berpengaruh terhadap kepatuhan wajib pajak. Dengan kata lain, kondisi keuagan perusaahaan dapat meningkatkan tingkat kepatuhan wajib pajak hotel. Semakin baik kondisi keuangan wajib pajak hotel maka semakin tinggi pula kepatuhan dari wajib pajak hotel. Hasil pengolahan data menunjukan bahwa kondisi keuangan berpengaruh positif terhadap tingkat kepatuhan wajib pajak. dapat disimpulkan bahwa secara parsial terdapat pengaruh positif dan signifikan antara kondisi keuangan dengan kepatuhan wajib pajak. Dengan demikian hipotesis keempat $\left(\mathrm{H}_{4}\right)$ diterima.

Adanya pengaruh kondisi keuangan perusahaan terhadap kepatuhan wajib pajak dalam penelitian ini, disimpulkan sama oleh Aryobimo (2012). Aryobimo membuktikan bahwa variabel kondisi keuangan perusahaan berpengaruh positif terhadap kepatuhan wajib pajak. Hal ini berbeda dengan hasil penelitian yang dilakukan oleh Tresno, Etty dan Suci (2010), bahwa kondisi keuangan wajib pajak tidak berpengaruh terhadap kepatuhan wajib pajak. serta memoderasi hubungan antara persepsi wajib pajak tentang kualitas pelayanan fiskus dengan kepatuhan wajib pajak.

Hasil penelitian ini diperkuat dari data Laporan Penerimaan Pendapatan Daerah. Rendahnya kepatuhan wajib pajak hotel pada tahun 2014-2015, yang terbukti dari tingginya denda pajak yang disebabkan 
pada tahun tersebut pendapatan hotel tidak mencapai target, yang disebabkan adanya Peraturan Menteri Aparatur Negara dan Birokrasi Republik Indonesia yang melarang kegiatan konsinyering di luar kantor instansi pemerintah. Pada kondisi tersebut wajib pajak hotel mengalami kesulitan likuiditas, kondisi keuangan yang tidak baik ini jelas menurunkan kepatuhan wajib pajak hotel. Hasil penelitian ini sejalan dengan teori bahwa pada umunya kondisi keuangan yang baik akan mendorong wajib pajak untuk patuh, karena kondisi keuangan tersebut menggambarkan keadaan perusahaan yang baik dan cukup memumpuni untuk memenuhi segala kebutuhannya seperti membayar hutang, bunga dan deviden, serta pajak yang merupakan kewajiban setiap wajib pajak (Tresno, Etty dan Suci, 2010).

d. $\mathrm{H}_{5}=$ Preferensi Resiko berpengaruh terhadap Kepatuhan Wajib Pajak.

Hipotesis ketiga $\left(\mathrm{H}_{5}\right)$ yang diajukan dalam penelitian ini adalah bahwa preferensi resiko berpengaruh terhadap kepatuhan wajib pajak. Dengan kata lain, resiko dalam kaitannya dengan kepatuhan mengarah pada kondisi yang muncul karena suatu ketidakpastian dengan suatu keadaan yang merugikan bagi perusahaan yang memungkinkan terjadinya ketidakpatuhan wajib pajak dan dapat merugikan bagi perusahaan. Ketika preferensi resiko memiliki hubungan yang kuat terhadap kepatuhan wajib pajak, maka tingkat kepatuhan wajib pajak akan rendah, yang artinya wajib pajak yang memiliki berbagai resiko yang tinggi akan dapat menurunkan tingkat kepatuhan wajib pajak. Dalam hal ini, wajib pajak hotel yang ada di Kabupaten Bogor rata-rata mengabaikan risiko yang ada sehingga mereka tidak memikirkan risiko yang akan muncul pada wajib pajak hotel didalam kegiatan perpajakan. Berdasarkan hasil penelitian, dapat disimpulkan bahwa secara parsial tidak terdapat pengaruh antara prefrensi resiko dengan kepatuhan wajib pajak. Dengan demikian hipotesis ketiga $\left(\mathrm{H}_{5}\right)$ ditolak.

Tidak adanya pengaruh preferensi resiko terhadap kepatuhan wajib pajak dalam penelitian ini, disimpulkan sama oleh Yulianti (2015). Peneliti tersebut membuktikan bahwa variabel prefrensi resiko tidak berpengaruh kepatuhan wajib pajak, hal ini diperkuat dengan pernyataannya bahwa Masalah atau risiko yang muncul merupakan persoalan bagi wajib pajak itu sendiri. Pemerintah maupun petugas pajak cenderung tidak memperdulikan risiko yang terjadi pada masing-masing wajib pajak dikarenakan pemerintah maupun petugas pajak hanya menjalankan prosedur yang berlaku.

\section{Variabel Dominan Berpengaruh terhadap Kepatuhan Wajib Pajak Hotel}

Berdasarkan hasil pengolahan data, variabel yang paling dominan dalam memberikan pengaruh terhadap kepatuhan wajib pajak hotel adalah variabel kondisi keuangan dengan probabilitas 0,011 lebih kecil dari taraf signifikansi 0,05, dibandingkan dengan variabel pemeriksaan pajak dan sanksi perpajakan yang hanya memberiksan pengaruh probabilitas sebesar 0,025 untuk variabel pemeriksaan pajak dan 0,021 untuk variabel sanksi perpajakan. Sedangkan variabel preferensi resiko tidak memiliki pengaruh terhadap kepatuhan wajib pajak dengan probabilitas sebesar 0,080. Artinya bahwa kondisi keuangan sangat dominan terhadap peningkatan kepatuhan wajib pajak, wajib pajak yang memiliki profitabilitas yang tinggi dan tidak dalam permasalahan kesulitan likuiditas memungkinkan mematuhi kewajiban perpajakannya dan dapat meningkatkan kepatuhan wajib pajak hotel.

\section{SIMPULAN}

1. Pemeriksaan pajak, sanksi perpajakan, kondisi keuangan dan preferensi resiko secara simultan berpengaruh terhadap kepatuhan wajib pajak hotel yang terdaftar pada BAPPENDA Kabupaten Bogor. Artinya semakin tinggi keempat faktor tersebut, maka semakin tinggi pula tingkat kepatuhan wajib pajak hotel yang terdaftar pada BAPPENDA Kabupaten Bogor.

2. Pemeriksaan pajak, sanksi pajak dan kondisi keuangan secara parsial berpengaruh positif terhadap kepatuhan wajib pajak hotel yang terdaftar pada BAPPENDA Kabupaten Bogor, sedangkan preferensi resiko tidak berpengaruh terhadap kepatuhan wajib pajak hotel 
yang terdaftar pada BAPPENDA Kabupaten Bogor.

3. Faktor yang berpengaruh dominan berpengaruh terhadap kepatuhan wajib pajak hotel yang terdaftar pada BAPPENDA Kabutaen Bogor ialah variabel kondisi keuangan.

\section{DAFTAR PUSTAKA}

\section{Adiasa, Nirwana., 2013, Pengaruh Pemahaman Peraturan Pajak Terhadap Kepatuhan Wajib Pajak dengan Preferensi Risiko sebagai Variabel Moderating, Skripsi Sarjana, Semarang: FE Universitas Negeri Semarang.}

Ali et al., 2001, The Effect Of Tax Rates and Enfoercement Policies on Tax Prayer Compliance. A Study of self employed tax prayer, Atlantic Economic Journal. 29 (2): June.

Alim, Setiadi., 2005, Perencanaan Pajak Penghasilan Yayasan Yang Bergerak di Bidang Pendidikan, Jurnal Akuntansi dan Teknologi Informasi IV(2).

Aryobimo, Putut Tri., 2012, Pengaruh Persepsi Wajib Pajak tentang Kualitas Pelayanan Fiskus terhadap Kepatuhan Wajib Pajak dengan Kondisi Keuangan Wajib Pajak dan Preferensi Risiko sebagai Variabel Moderating (Studi Empiris terhadap Wajib Pajak Orang Pribadi di Kota Semarang), Skripsi Sarjana, Fakultas Ekonomi dan Bisnis Universitas Diponegoro, Semarang. http://eprints.undip.ac.id/37354/1/A RYOBIM0.pdf (diakses pada 28 Oktober 2016 pukul 11:08 wib)

Bloomqist, K. M., 2003, Income Inequality and Tax Evation : A Systhensis. Tax Notes Internasional, 31(4), 347 -346.

Bradley, Cassie Francies., 1994, An Empirical Investigation of Factor Affecting Corporate Tax Compliance Behavior. Dissertation. The University of Alabama, USA.

Dewi, Putu Septiana dan I Made Sukarta., 2015, Faktor-Faktor Yang Mempengaruhi Kepatuhan Wajib Pajak Dalam Membayar Pajak Hotel, Bali: Fakultas Ekonomi dan Bisnis Universitas
Udayana (Unud),Vol.13.No.2 Nov. 2015. (hal 599-614), ISSN: 2302-8556

Ghozali, Imam., 2007, Aplikasi Analisis Multivariate dengan Program SPSS.Semarang: Badan Penerbit Universitas Diponegoro.

Hidayat, Nur., 2005, Prioritas Dalam Pemeriksaan Pajak, Fakultas Ekonomi, Bandung: Universitas Kristen Maranatha.

Jatmiko, Agus Nugroho., 2006, Pengaruh Sikap Wajib Pajak pada Pelaksanaan Sanksi Denda, Pelayanan Fiskus dan Kesadaran Perpajakan Terhadap Kepatuhan Wajib Pajak (Studi Empiris Terhadap Orang Pribadi di Kota Semarang), Tesis, Semarang: Universitas Diponogoro.

Mardiasmo, 2011, Perpajakan, Edisi Revisi. Yogyakarta: Andi

Nasucha, Chaizi, Dr., 2004, Reformasi Administrasi Publik: Teori dan Praktik, Jakarta: Penerbit PT. Gramedia Widiasarana Indonesia.

Peraturan Pemerintah Republik Indonesia No. 91 Tahun 2010 Tentang Jenis Pajak Daerah Yang Dipungut Berdasarkan Penetapan Kepala Daerah Atau Dibayar Sendiri Oleh Wajib Pajak. http://www.djpk.depkeu.go.id/attach/ post-pp-no-91-tahun-2010-tentangjenis-pajak-daerah-yang-dipungutberdasarkan-penetapan-kepaladaerah-atau-dibayar-sendiri-olehwajib-pajak/--603-815PP No 91 Tahun 2010.pdf (diakses pada 2 Desember 2016 pukul 15:21 wib)

Priantara, Diaz., 2000, Pemeriksaan dan Penyidikan Pajak, Jakarta: Djembatan.

Puspita, Ayu Fury, Bambang Subroto, Zaki Baridwan., 2016, The Analysis of Individual Behaviour of Corporate Taxpayers' Obedience: Tax Compliance Model (Study of Hotels in Malang and Batu), Rev. Integr. Bus. Econ. Res. Vol 5(3). http://sibresearch.org/uploads/3/4/0 /9/34097180/riber b16-099 135160.pdf (diakses pada 2 Desember 2016 pukul 14:03 wib)

Savitri dan Musfialdy., 2016, The Effect of Taxpayer Awareness, Tax Socialization, Tax Penalties, Compliance Cost at Taxpayer 
Compliance with Service Quality as Mediating Variable, Pekanbaru: Fakultas Ekonomi Universitas Riau, 3rd Global Conference on Business and Social Science-2015, GCBBS-2015, 1617 Desember 2015, Kuala Lumpur Malaysia.

Siahaan, Fadjar O.P., 2005, Faktor-Faktor yang Memepengaruhi Perilaku kepatuhan Tax Professional dalam Pelaporan Pajak Badan pada Perusahaan Industri Manufaktur di Surabaya, Disertasi Program Pascasarjana Universitas Airlangga.

Supadmi, Niluh., 2009, Meningkatkan Kepatuhan Wajib Pajak melalui Kualitas Pelayanan, Jurnal Ilmiah Akuntansi \& Bisnis, Vol.4.No.2.

Tresno, Etty, Suci., 2011, Pengaruh Persepsi Tentang Sanksi Perpajakan, Kesadaran Wajib Pajak dan Kondisi Keuangan Perusahaan Terhadap Kepatuhan Pelaporan Wajib Pajak Badan, Universitas Negeri Jakarta.

Torgler, B., 2003, Tax Morale : Theory and Analaysis of Tax Compliance, Unpublished doctoral dissertion, University of Zurich, Switzerland.

B., 2005, Tax Moral and Direct Democracy. Europan Journal of Political Economy, 21,h:525-531.

Trisnawati, Ni uh Mika., 2015, Analisis Faktor-Faktor yang Mempengaruhi Kepatuhan Wajib Pajak Membayar Pajak Hotel, Pajak Restoran dan Pajak Hiburan di Kota Denpasar, Tesis, Pascasarjana Universitas Udayana, Denpasar.

Yulianty, Eka., 2015, Pengaruh Pemahaman Peraturan Perpajakan Terhadap Kepatuhan Formal Wajib Pajak Dengan Preferensi Risiko Sebagai Variabel Moderating (Studi Kasus pada WPOP KPP Pratama Makassar Utara), Skripsi, Makasar: Fakultas Ekonomi dan Bisnis Universitas Hasanuddin. 